\title{
APOPTOSIS AND EXPRESSION OF BCL-2 IN HUMAN ENDOMETRIUM IN NATURAL AND ARTIFICIAL CYCLES
}

\author{
Pavel Havelka ${ }^{a}$ Ivana Obornáb Jana Březinováb, Václav Lichnovskýa \\ a Institute of Histology and Embryology, Faculty of Medicine, Hněvotínská 3, Palacky University, 77515 Olomouc, Czech \\ Republic \\ ${ }^{b}$ Department of Obstetrics and Gynaecology, University Hospital, I. P. Pavlova 6, 77520 Olomouc, Czech Republic \\ e-mail: havelka@bnzlin.cz
}

Received: August 1, 2005; Accepted (with revisions): November 18, 2005

Key words: Apoptosis/Bcl-2/Secretory endometrium/Oral estrogen-progesterone substitution

Apoptosis plays a significant role in differentiation of many organs and helps to maintain homeostasis. The occurrence of apoptosis (using the apoptotic index) and expression of regulation protein Bcl-2 in the human endometrium was evaluated within the secretory phase of both the natural cycle, and an artificial one.

Oral hormonal substitution used in this design induced similar, but more marked dynamic changes in Bcl-2 expression in the mid-secretory endometrium as were observed in the natural cycle, primarily in the surface and glandular epithelium of the endometrium. The apoptosis revealed similar a trend, but not significantly different.

\section{INTRODUCTION}

Every second, several thousands of new cells are created in the human organism to replace damaged cells, or cells, which have already served their biological purpose. This process, termed proliferation, must be, and is, accompanied by cell death. Maintaining a steady balance between these two basic processes is part of one of the organism's mechanisms for ensuring homeostasis. Simply put, cell death can occur by two processes, which have an effect not only on the cell itself, but also on its' surroundings. While the first process, termed oncosis (necrosis), is characterized by swelling of the cell, vacuolization, increased permeability of cell membranes and gradually even a surrounding inflammatory reaction, the second process, so-called apoptosis or programmed cell death (PCD), consists of the splicing of DNA by specific endonucleases and this leads to the formation of apoptotic bodies, which are then eliminated by specific macrophages, with no surrounding inflammatory reaction ${ }^{1}$.

The process of cell death was morphologically described at the end of the $19^{\text {th }}$ century, but not until 1972 was it defined by authors Kerr and Williams, who also coined the term apoptosis ${ }^{2}$. Unlike oncosis, PCD is an active process, which includes a number of regulatory mechanisms located on the cell surface, in mitochondria, cytoplasm and in the cell nucleus. Due to new findings in the field of molecular biology, it has been possible to monitor and describe programmed cell death in many organs of the human organism. Apoptosis may be observed doing the course of embryonic development of many organs s $^{3,4}$, and it participates in the involution of the thymus and of the mammary gland after nursing $g^{5,6,7}$.
Apoptosis was also monitored in the human endometrium during the menstrual cycle. Follicular phase is characterized by rapid cell proliferation, which is predominantly controlled by ovarian estrogens, but also other substances play their specific role, cellular growth factors - angiogenetic growth factor, epidermal growth factor, fibroblast growth factor etc ${ }^{8}$. In the luteal phase, progesterone is present and initiates and greatly influences secretory differentiation of the endometrium. PCD is also introduced in this phase of the menstrual cycle and its levels increase with the forthcoming menstruation, and as such it participates in endometrial regeneration, along with ischemia and necrosis.

Among the most significant PCD regulators are proteins from the bcl-2 family. Representatives of this significant group of regulation factors may act as inducers as well as suppressors of apoptosis. Antiapoptotic proteins include, for example, Bcl-2, Bcl- $\mathrm{X}_{\mathrm{L}}$, Bcl-w; proteins, which have proapoptotic activity, include Bax, Bak, Bid and others. These two protein groups are able to create homodimers and heterodimers between each other and the resulting effect (pro- or antiapoptotic) depends on the potential dominance of one of them. The best-studied protein is Bcl-2, which acts as an antioxidant in the cell, protects cytochrome $\mathrm{C}$ from being released from mitochondria and participates in the regulation of caspase proteins ${ }^{1}$. Since the antiapoptotic activity of the Bcl-2 protein enables cell survival, it can thereby partake in tumor proliferation as well as in its chemoresistence. The presence of the Bcl-2 protein in the physiological endometrium, as well as in the endometrium of various pathologies, has been monitored. Increased expression was noted in the proliferation phase of the menstrual cy- 


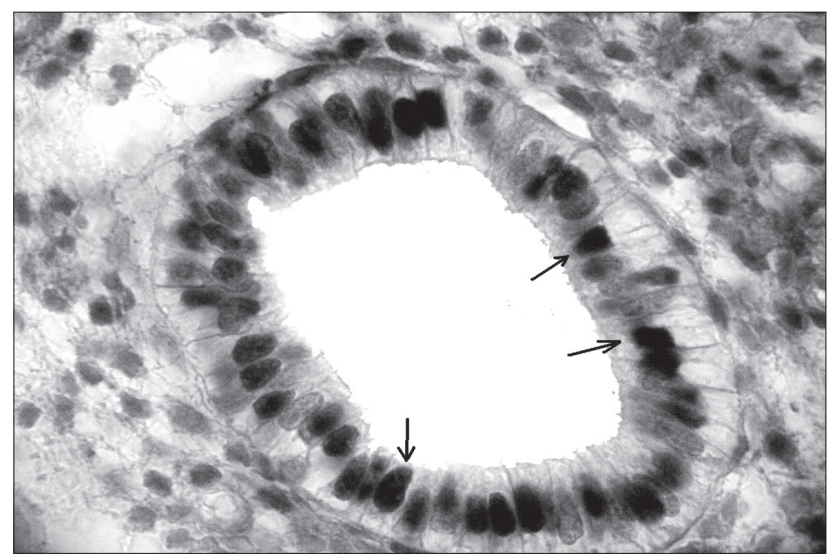

Fig. 1. The occurrence of apoptosis in the surface of the epithelium a in the glandular cells ( $\uparrow$ ). Massive expression was detected in both layers. Magn. 400×

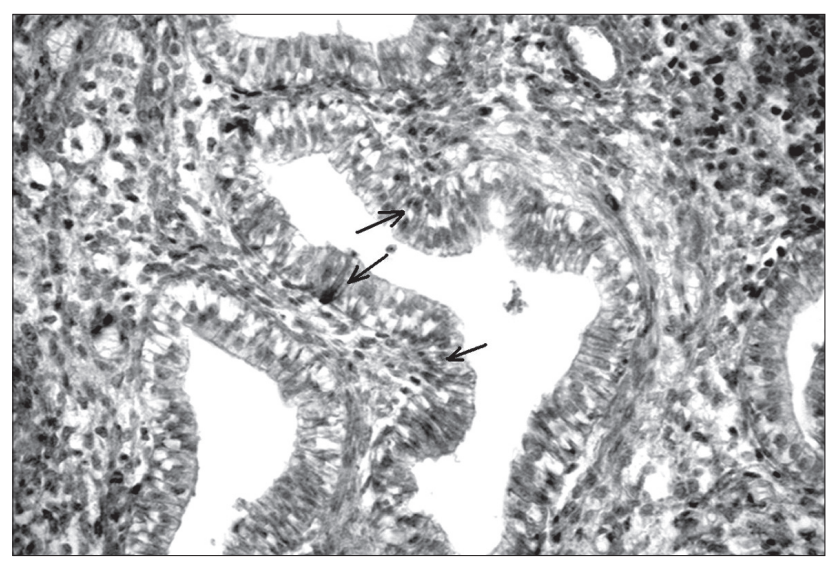

Fig. 3. The occurrence of Bcl-2 protein in the glandular cells of compact layer. Magn. 400×

cle with gradual decrease during the secretory phase to a total absence in premenstruum ${ }^{9,10,11}$.

The aim of our study was to find out whether hormonal preparation of the endometrium induces similar expression of Bcl-2 and level of apoptosis in individual structures in the mid-secretory endometrium. The changes in the natural menstrual cycle, as well as in the experimental artificial cycle, where the endometrium was prepared by oral estrogen-progesterone substitution in the same group of patients were evaluated, since this hormonal preparation of the endometrium is regularly used in patients prepared for transfer of cryopreserved - thawed embryos.

\section{MATERIAL AND METHODS}

Study group: Twenty-three infertile women who had cryopreserved embryos in pronuclear (PN) stage from previous IVF cycle were recruited in a single infertility centre. All women gave their informed written consent to the study, which was approved by the Institutional Review Board of the Palacký University.

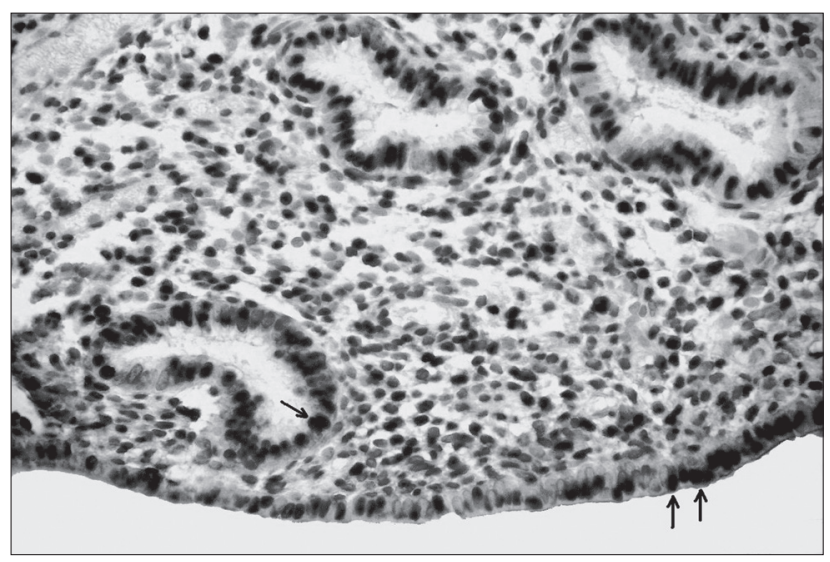

Fig. 2. The expression of apoptosis in the glandular cells. Magn. 400×

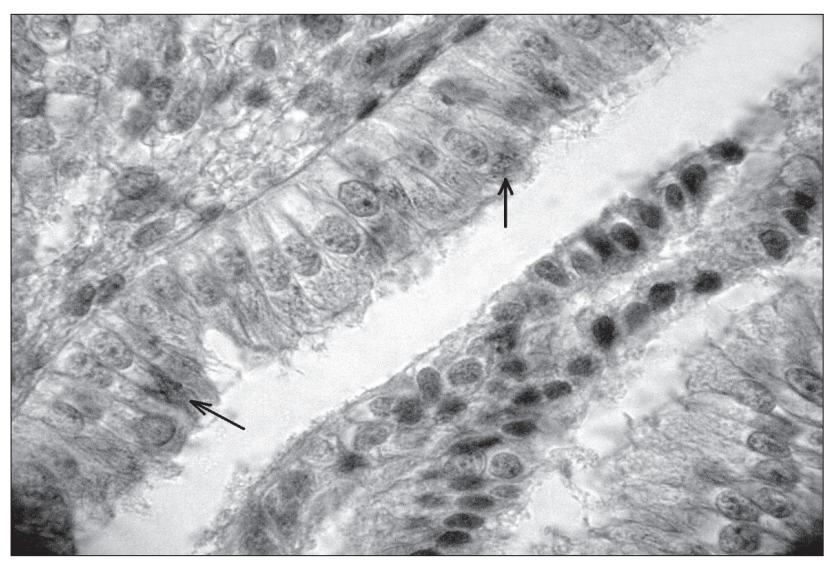

Fig. 4. The occurrence of Bcl-2 protein in the glandular cells of spongious layer. Magn. $600 \times$

The women had a history of infertility of more than 12 months, were less than 40 years old, had regular menstrual cycle with normal concentration of serum progesterone in the mid-luteal phase, physiological basal serum levels of FSH $(<10 \mathrm{IU} / 1)$ and prolactin on the $3^{\text {rd }}$ day of the cycle previously. Patients were examined in the course of two menstrual cycles.

1. Spontaneous cycle: All subjects monitored their own urinary LH excretion daily from cycle day 10 using Simtech (Biores Inc, USA). From cycle day 11, repeated vaginal ultrasound examination (Hewlett Packard, probe 7,5 MHz) was performed until ovulation (day 0). Endometrial biopsies were performed on luteal days +5 and +7 .

2. Artificial cycle: Hormonal substitution was started on the first day of a second cycle using progressively increasing doses of estradiol-valerate $(2 \mathrm{mg} / \mathrm{d}$ from day 1 to $6,4 \mathrm{mg} / \mathrm{d}$ from day 7 to 10 and $6 \mathrm{mg} / \mathrm{d}$ from day 11 to 15 ). If on day 15 the endometrial thickness reached $8 \mathrm{~mm}$ or more micronised progesterone $(\mathrm{P})$ was added in a dose $600 \mathrm{mg} / \mathrm{d}$ and the dose of estradiol-valerate was decreased to $4 \mathrm{mg} / \mathrm{d}$. Endometrial biopsies were taken on days 5 and 7 of $\mathrm{P}$ addition. 
Tissue collection: Uterine endometrial sequential biopsies were taken within an interval of 48 hours using Novak curette by a single investigator while the patient was under sedation. The first biopsy was taken from the right side, second, two days later, from the left side of anterio-fundal area of the uterus to ensure that the second sample was taken from a different area. Bioptic samples were fixed in methacarn for 24 hours and embedded in paraffin. Sections $(7 \mu \mathrm{m})$ were pre-treated by expossure to microwave or Proteinase K. The occurrence of apoptosis and expression of Bcl-2 protein was evaluated in 92 samples of mid-secretory endometrium.

Apoptosis: This was detected using a TUNEL kit (Roche) separately in stromal cells, spongy and compact layers of glands. Apoptosis (apoptotic index-AI) was determined semi quantitatively - according to the number of positive cells in individual structures by dividing samples into 7 categories $(0 \%, 0-0 \%, 10-20 \%, 20-35 \%, 35-50 \%$, $50-75 \%$ and $75-100 \%)$.

Bcl-2 protein: It was estimated by an indirect three-step immunohistochemical method using anti-Bcl-2 (Biogenex) as a primary antibody and biotin labeled anti-mouse IgG (Biogenex) as a secondary antibody. Biotin creates a strong specific bond with streptavidin, which is enzymatically conjugated (alkaline phosphatase). In the tissue, the enzyme then reacts with the supplied substrate diaminobenzidin (Fluka), and a colored product is formed.

The degree of Bcl-2 expression was also determined semi quantitatively - according to the number of positive cells (presence of Bcl-2) in individual structures of the endometrium and the samples were divided into 7 categories: $0 \%, 0-10 \%, 10-20 \%, 20-35 \%, 35-50 \%, 50-75 \%$ and $75-100 \%$.

Four structures were separately evaluated in the endometrium - surface epithelium, stroma, and glandular epithelium in the compact layer, and the spongious layer.

Statistical evaluation: This was performed by $\chi^{2}$ test, $\mathrm{p}$ $<0.05$ was considered statistically significant.

\section{RESULTS}

The results of our comparison study are depicted in the following figures.

Apoptosis: In the natural cycle, the occurrence of apoptosis increased between the 5 th and 7 th day after ovulation in all monitored endometrial structures. Occurrence was statistically significant in surface epithelium $(p<0,02)$ and in glands of the spongious layer $(p<0,05)$.

In the artificial cycle the situation was similar with no significant changes. A relatively small number of apoptotic cells are seen in the stroma of the endometrium and again the highest occurrence of apoptosis is seen in the surface epithelium and in glands of the spongious layer. When apoptosis was compared in the two evaluated cycles, no significant differences were found.

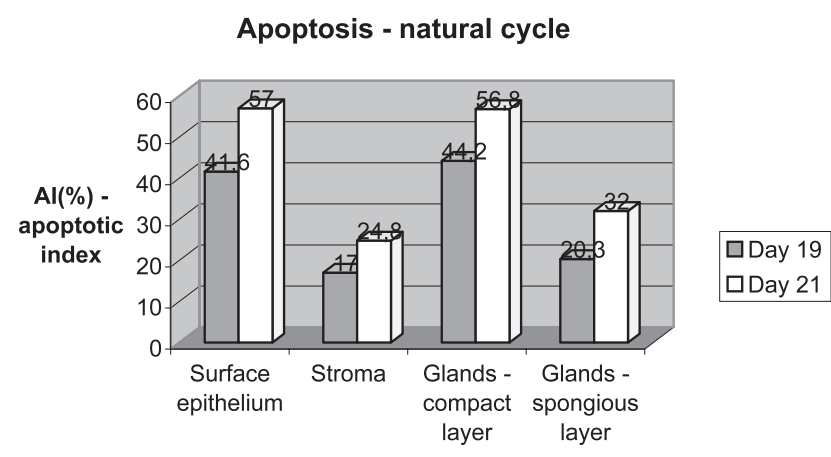

Fig. 5. The occurrence of apoptosis in the natural cycle.

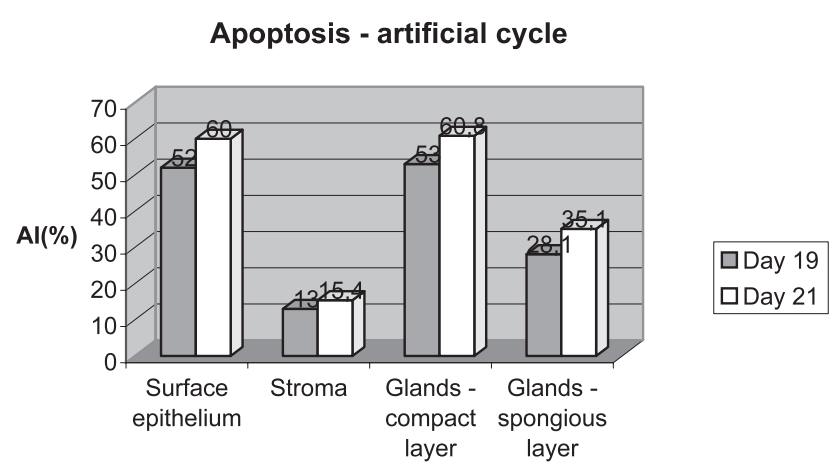

Fig. 6. The occurrence of apoptosis in the artificial cycle.
$\mathrm{Bcl}-2$ - natural cycle

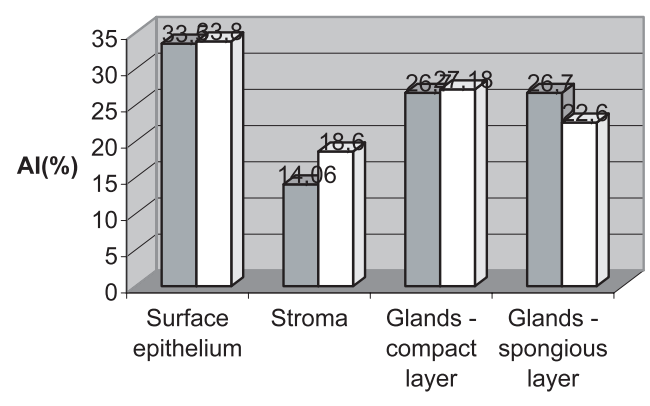

Fig. 7. The occurrence of Bcl-2 protein in the natural cycle.
Bcl-2 - artificial cycle

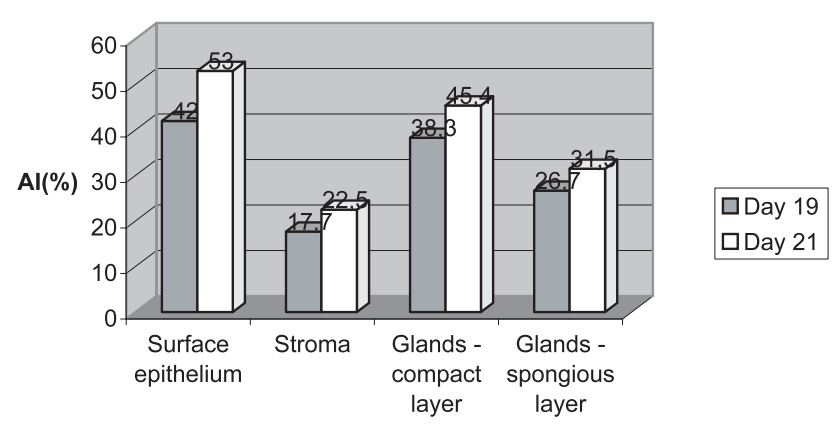

Fig. 8. The occurrence of Bcl-2 protein in the artificial cycle. 
Bcl-2 protein: No significant fluctuations in the presence of the antiapoptotic protein Bcl-2 were observed in the spontaneous cycle in the mid-luteal phase, only the surface epithelium showed a slight increase, and the glands of the spongious layer showed a decrease in the number of positive cells, without statistical significance. Quantitative differences in the number of cells positive for the protein $\mathrm{Bcl}-2$ however may be seen in the artificial cycle. All monitored layers of endometrium show an increase on the $7^{\text {th }}$ day after progesterone application when compared to the $5^{\text {th }}$. The greatest difference was observed in the surface epithelium $(p<0,05)$, with similar findings in the other structures, but without statistical significance.

A greater differentiation may be seen if we compare both types of cycles. Here an increased expression of Bcl-2 protein was observed in artificial cycles in surface epithelium $(p<0,05)$ and in glands of the compact layer $(\mathrm{p}<0,05)$, as well as in spongious layer $(\mathrm{p}<0,05)$.

\section{DISCUSSION}

Since 1972, when Kerr et al. first defined apoptosis as one form of cell death, its occurrence in many tissues has been monitored with increasing interest. The occurrence of apoptotic cells in the endometrium during the menstrual cycle have been described by many authors ${ }^{12,13,14}$. A very low occurrence of apoptosis is noted during the proliferative phase and at the beginning of the secretory phase, where it is present primarily at the epithelial cells of the endometrium. The level of apoptosis in the stroma was lower than in the surface and glandular epithelium and failed to increase until the beginning of menstruation; that is about 2 days later than in the epithelium. A maximum of apoptotic index (AI) was noted on 2 day after the beginning of menstruation ${ }^{9,10}$. Similarly in our study, which evaluated the mid-luteal phase of the cycle, the AI increases on the second day of collection, primarily in the epithelial cells, while the stroma cells contain barely half the number of apoptotic cells. These observations suggest a hormonal influence on apoptosis during the menstrual cycle, which is relatively independent of menstrual bleeding. The proliferation phase of the menstrual cycle is mainly influenced by estrogen, which promotes cell proliferation. In such cases, estrogen plays the role of a cell saving factor by inhibiting apoptosis either directly or by way of growth factors or cytokines. The receptors Fas and their ligands FasL probably significantly contribute to this process of induction or inhibition of apoptosis in the endometrium. These membrane receptors belong to the TNFR (tumor necrosis factor receptor) group and their ligands, which after binding to the receptor, can induce apoptosis, belong to the TNF (tumor necrosis factor) family.

Fas and FasL are expressed in the endometrium during the menstruation cycle with an increased expression during the secretory phase in comparison to the proliferation phase $\mathrm{e}^{15,16}$. During proliferation they are localized in cells inside the cytoplasmic vesicles and in the Golgi apparatus and it is not until the secretory phase that they become part of the membranes, where they are able to bind FasL and induce apoptosis. Ovarian hormones regulate this entire process. Many studies have shown that Fas-mediated apoptosis is inhibited by the presence of estrogen and progesterone, and their elimination (menstrual phase) or the addition of an antiprogestin is followed by an increased Fas and FasL expression which results in an increase in apoptosis ${ }^{17,18}$. These studies demonstrate an increase in FasL expression in the presence of estrogen, which aids in maintaining a balance between cell proliferation and apoptosis.

Our study also shows an AI increase as menstruation approaches, and this is seen in both monitored cycles, spontaneous as well as artificial. The difference was greater in the spontaneous cycle, primarily in surface and glandular epithelium, while the hormonal substitution cycle did not exhibit such remarkable differences. In the hormonal substitution cycle, a certain increase in apoptosis is observed in the epithelial cells on the $19^{\text {th }}$ day of the cycle. However, this increase is not very remarkable. To what extent these two mentioned hormones regulate apoptosis is not quite clear. According to previous studies, the higher estrogen level should "protect" cells from death by apoptosis. Our results show a relative independence of programmed cell death from the serum level of steroid hormones as related to the approaching menstruation. The level of apoptosis in mid luteal phase of spontaneous and artificial cycles found in this study was individually variable. The reasons for this variability may be multiple: individual variability in bioavailability of orally administered ovarian steroids due to polymorphism of isoforms of cytochrome $\mathrm{P} 450$ in intestinal wall, short halftime of $\mathrm{P}$ elimination after oral administration etc ${ }^{19}$. In some cases the focal positivity of staining for apoptosis seen more often in stroma may lead to bias in the results ${ }^{20}$.

It is however possible to affect apoptosis through the action of regulatory proteins, of which proteins from the so-called bcl-2 family are most significant, primarily Bcl-2. Although all the mechanisms affect apoptosis during the menstrual cycle, it is assumed that Bcl-2 inhibits apoptosis during its proliferation phase $\mathrm{e}^{11,21}$. Its decrease in the late secretory and menstrual phase $\mathrm{e}^{22,23,24}$ corresponds to the discovery of apoptosis in this period of the cycle. This assumes a hormonal influence on the expression of this regulatory protein. Bcl-2 is observed in greater quantities in glandular cells and in the basal layer, where it can still be seen during the secretory phase ${ }^{25,26}$, whereas the Fas receptors are more intensely present in the functional layer of the endometrium ${ }^{23,27}$. This layer also undergoes more extensive cyclic changes during proliferation, differentiation, and finally elimination during menstruation. The decrease in Bcl-2 expression correlates with the decrease in the presence of progesterone (PR) and estrogen (ER) receptors in the secretory phase of the endometrial cycle $\mathrm{e}^{10,28}$. The correlation between Bcl-2 and PR was observed in endometrial hyperplasia and in highly differentiated ade nocarcinomas ${ }^{29,30,31}$. In contrast, this regulatory protein 
is present, in very small quantities, in the endometrium of postmenopausal women. All these studies assume a hormonal regulation of $\mathrm{Bcl}-2$, where estrogen increases its expression and progesterone decreases it.

The presence of Bcl-2 in uterine myomas, however, shows an inverse relationship, with increased expression in the secretory phase, which is predominantly regulated by progesterone, as well as a decrease after therapy with this hormone ${ }^{32}$.

We can conclude that oral hormonal substitution used in this design induced similar, but more marked dynamic changes of Bcl-2 expression in the mid-secretory endometrium as were observed in the natural cycle, primarily in the surface and glandular epithelium of the endometrium. The apoptosis revealed a similar trend, but this was not significant.

\section{ACKNOWLEDGEMENT}

Supported by grant IGA NH 6611/3 Endometrial receptivity in relation to cryopreserved embryos' transfer success rate.

\section{REFERENCES}

1. Kolář Z a kol. (2003) Molekulární patologie nádorů, Epava, Olomouc, 33-38

2. Kerr JFR, Wyllie AH, Currie AR (1972) Apoptosis: a basic biological phenomenon with wide ranging implication in tissue kinetics. Br. J. Cancer 26, 239-257

3. Procházková J, Lichnovský V, Kylarová D, Erdösová B. (2004) Involvement of p53 and Bcl-2 family proteins in regulating programmed cell death and proliferation in human embryogenesis. General Physiology Biophysics. 23, 209-229

4. Lichnovský V, Havelka P, Erdösova B, Procházková J. (2001) The role of apoptosis and its regulating genes during differentiation of myocardium of human embryos. Sborník lékařský, Vol. 102, No. 2, 201-20

5. Cohen JC, Duke RC. (1984) Glucocorticoid activation of a calcium - dependent endonucleasein thymocyte nuclei leads to cell death, J Immunol., Jan; 132, 38-42.

6. Quarrie LH, Addey CVP, Wilde CJ. (1995) Apoptosis in lactating and involuting mouse mammary tissue demonstrated by nick-end DNA labelling. Cell Tissue Res., Sep, 281, 413-9.

7. Lund LR, Romer J, Thomasset $\mathrm{N}$ et al. (1996) Two distinct phases of apoptosis in mammary gland involution: proteinase-independent and-dependent pathways. Development. 1996 Jan, 122, 181-93.

8. Ferin M, Jewelewicz R, Warren M. (1997) Menstruační cyklus, Grada, Praha, 1. vydání, 80-83

9. Vaskivuo TE, Stenbäck F, Karkumaa P, Risteli J, Dunkel JS, Tapanainen JS. (2000) Apoptosis and apoptosis-related proteins in human endometrium. Mol Cell Endocrinol 165, 75-83

10. Dahmoun M, Boman K, Cajander S, Westin P, Bäckström T. (1999) Apoptosis, proliferation, and sex hormone receptors in superficial parts of human endometrium at the end of the secretory phase. J clin Endocrinol Metab 84, 1737-1743

11. Otsuki Y, Misaki O, Osamu S et al. (1994) Cyclic bcl-2 gene expression in human uterine endometrium during menstrual cycle. Lancet, Vol. 344, 28-30.

12. Hopwood D, Levinson DA. (1976): Atrophy and apoptosis in the cyclical human endometrium. J Pathol., 119, 159-166.

13. Kokawa K, Shikone T, Nakano R. (1996) Apoptosis in the Human Uterine Endometrium during the Menstrual Cycle. J. Clin Endocrinol Metab. 81, 4144-4147
14. Shikone T, Kokawa K, Yamoto M, Nakano R. (1997) Apoptosis of human ovary and uterine endometrium during the menstrual cycle. Horm Res. 4, Suppl 3, 27-34

15. Yamashita H, Otsuki Y, Ito Y et al. (1999) Fas ligand, Fas antigen and $\mathrm{Bcl}-2$ expression in human endometrium during the menstrual cycle. Mol Hum Reprod. 1999 Apr., 5, 358-64.

16. Watanabe H, Kanzaki H, Narukawa S. et al. (1997) Bcl-2 and Fas expression in eutopic and ectopic human endometrium during the menstrual cycle in relation to endometrial cell apoptosis. Am J Obstet Gynecol. 1997 Feb, 176, 360-8.

17. Rotello RJ, Lieberman RC, Lepoff RB, Gerschenson LE. (1992) Characterization of uterine epithelium apoptotic cell death kinetics and regulation by progesterone and RU 486. Am J Pathol 140, 449-456

18. Song J, Rutherford T, Naftolin F et al. (2002) Hormonal regulation of apoptosis and the Fas and Fas ligand system in human endometrial cells. Mol Hum Reprod., 8, 447-55.

19. Fingerová H, Oborná I, Petrová P, Budíková M, Jezdínský J. (2003) Zvyšuje grapefruitová štáva biologickou dostupnost orálně podávaných sexuálních steroidů?, Česká Gynekologie 2003, 68, 117-121

20. Havelka P, Oborná I, Lichnovský V, Kršková M, Fingerová H., Březinová J. (2004) Porovnání exprese apoptozy v sekrečním endometriu přirozeného menstruačního cyklu Česká Gynekologie, 69, 15-19

21. Koh ETA, Illingworth PJ, Duncan WC et al.(1995) Immunolocalization of Bcl-2 protein in human endometrium in the menstrual cycle and simulated early pregnancy. Hum Reprod, 10, 1557-1562

22. Konno R, Yamakawa H, Utsunomiya H et al. (2000) Expression of survivin and Bcl-2 in the normal human endometrium. Mol Hum Reprod. 2000 Jun, 6, 529-34.

23. Jones KJ, Searle RF, Bulmer JN. (1998) Apoptosis and bcl-2 expression in normal human endometrium, endometriosis and adenomyosis. Hum. Reprod., 13, 3496-3502.

24. Gompel A, Sabourin JC, Martin A et al. (1994) Bcl-2 expression in normal endometrium during the menstrual cycle. Am. J. Pathol., 144, 1195-1202.

25. Tao XJ, Tilly KI, Maravei DV, Shifren JL, Krajewski S, Reed JC. (1997) Differential expression of members of the bcl-2 gene family in proliferative and secretory human endometrium: Glandular epithelial cell apoptosis in associated with increased expression of bax. J Clin Endocrinol Metab 82, 2738-2746

26. Oborná I, Havelka P, Lichnovský V, Březinová J, Fingerová H. (2005) Exprese proteinu bcl-2 v sekrečním endometriu po perorální estrogen-progesteronové substituci. Česká Gynekologie, 70, 62-66

27. Rogers PA, Lederman F, Plunkett D et al. (2000) Bcl-2, Fas and caspase 3 expression in endometrium from levonorgestrel implant users with and without breakthrough bleeding. Hum Reprod. 2000 Aug, 15 Suppl 3, 152-61.

28. Fung HYM, Wong YL, Wong FWS et al. (1994) Study of oestrogen and progesterone receptors in normal human endometrium during the menstrual cycle by immunocytochemical analysis. Gynecol Obstet Invest., 38, 186-90.

29. Saegusa M, Kamata Y, Isono M et al. (1996) Bcl-2 expression is correlated with a low apoptotic index and associated with progesterone receptor immunoreactivity in endometrial carcinomas. J Pathol. 1996 Nov, 180, 275-82.

30. Bozdogan Ö, Atasoy P, Erekul S et al. (2002) Apoptosis-related proteins and steroid hormone receptors in normal, hyperplastic and neoplastic endometrium. Int. J. Gynecol. Pathol., 21, 375-382.

31. Kokawa K, Shikone T, Otani T et al. (2001) Apoptosis and the expression of Bax and Bcl-2 in hyperplasia and adenocarcinoma of the uterine endometrium. Hum Reprod. 2001 Oct, 16, 2211-8.

32. Matsuo H, Maruo T, Samoto T. (1997) Increased expression of $\mathrm{Bcl}-2$ protein in human uterine leiomyoma and its up-regulation by progesterone. J Clin Endocrinol Metab. Jan, 82, 293-9. 